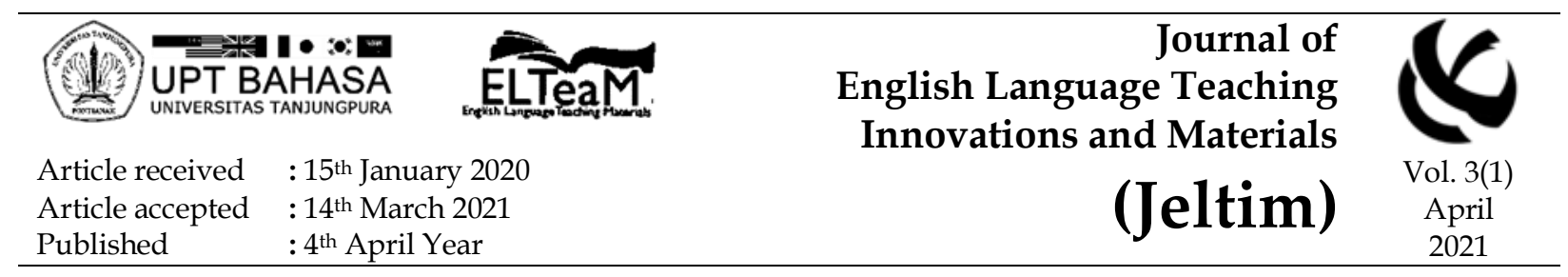

\title{
English varieties in the Year-7 coursebook taught in Indonesia
}

\section{Yuni Hardianti'1, Sudarsono Sudarsono ${ }^{2}$}

${ }^{1}$ Master Study Program of English Language Education, Teacher Training and Education Faculty, Tanjungpura University, Pontianak, Indonesia

yunihardianti191992@gmail.com

${ }^{2}$ Master Study Program of English Language Education, Teacher Training and Education Faculty, Tanjungpura University, Pontianak, Indonesia sudarsono@fkip.untan.ac.id

\section{DOI: http://dx.doi.org/10.26418/jeltim.v3i1.39096}

\begin{abstract}
The present research was designed to investigate the English varieties encountered in an English coursebook applied throughout Indonesia. It applied a descriptive analysis. The data were sorted out from corpora. The research found out that the coursebook applied in Indonesian schools included different varieties of English. They were American, British, and American and British-like. The varieties here covered vocabulary, spelling, and grammar.
\end{abstract}

Keywords: English Variety; English Coursebook; Descriptive Analysis.

How to cite this paper: Hardianti, Y., \& Sudarsono, S. (2021). English varieties in the Year-7 coursebook taught in Indonesia. Journal of English Language Teaching Innovations and Materials (Jeltim), 3(1), 39-47. DOI: http:/ / dx.doi.org/10.26418/jeltim.v3i1.39096

English is a foreign language taught compulsorily throughout Indonesia. As a foreign language subject, English is taught to enable the students to interact and to work with other people in international networks (Sudarsono, 2018). There are various Englishes spoken throughout the globe. The English varieties refer to that spoken predominantly by native speakers of English in Britain, the U.S, Canada, South Africa, Australia, and New Zealand (Sudarsono, 2018 \& Bauer, 2002). Besides, English is spoken as a lingua franca between the speakers who cannot communicate with each other due to different languages. When travelling to Paris for instance, an Indonesian speaks English to the taxi driver there to settle down the communication constraint because he cannot speak French, and the taxi driver does not understand Indonesian.

Journal of English Language Teaching Innovations and Materials (Jeltim), 3(1), 39-47

Copyright ( 2021 by Jeltim, e-ISSN 2657-1617 
An important issue in teaching English as a foreign language (TEFL) deals with the English varieties, that are spoken not only in the English predominantlyspeaking countries, but also in the outer-circle countries such as Singapore, India, and Nigeria. The English varieties in the outer-circle countries may be influenced very much by the local language properties such as pronunciation, vocabulary, and grammar, and they frequently develop to underserve different purposes. Therefore, the English spoken in the outer-circle countries may immediately "become mutually unintelligible" (Zacharias, 2003). To keep the speakers of English throughout the world interacting in the mutually intelligible English, it is required to have 'one common standard' (Zacharias, 2003) to derive universally intelligible standard English (Crystal, 2003).

To teach English in Indonesia, the Ministry of Education and Culture, the Republic of Indonesia, needs to publish the English coursebooks as the official sources for the teachers and the students to carry out the teaching-learning activities. Waltermann \& Forel (2015) urge that coursebooks play important roles in classrooms where the teachers and the students work together. It is "an almost universal element of ELT teaching" (Hutchinson \& Torres, 1994).

Indonesian coursebook writers may include various Englishes in their English coursebooks. Thus, it is significant to analyse what English they cover in the textbook applied in schools. The present study was designed to investigate the consistency in introducing English to the students through their coursebooks. The data were sorted out from a coursebook of English to represent other coursebooks available in secondary schools throughout Indonesia.

The clear distinction between British and American English lies in the pronunciation, particularly with the sound of vowels. For instance, the pronunciation of vowel 'a' as in 'class'. British English speakers pronounce it /kla:s/ and the American English speakers / klæs/. Another difference between these two varieties deals with / $\mathrm{r}$ / sound at the end of words or syllables like in 'car'. It is pronounced clearly by the American English speakers / 'kär/, but not by the British English speakers/ka:(r)/.

Grammatically, these two varieties of English differ in some issue like the verb 'get'. It is conjugated into 'got' by the British English speakers, and 'gotten' by the American English speakers to derive the past participle verb form as underlined respectively in the following sentences.

(1a) John has got much better during the last week.

(1b) John has gotten much better during the last week.

Another grammatical difference between English varieties deals with the verb 'have'. Unlike the American English speakers, the British English speakers function it not only as a lexical verb, meaning 'own, possess, dominate', but also

Journal of English Language Teaching Innovations and Materials (Jeltim), 3(1), 39-47

Copyright ( 2021 by Jeltim, e-ISSN 2657-1617 
as an auxiliary verb, equivalent with the auxiliary verb 'do' in American English. These two varieties also differ in the use of prepositions like 'in' and 'on'. The British English speakers use a temporal or spatial preposition before their respective oblique like home and Monday. But, the American English speakers may delete it. Their respective examples are shown below.

(2a) Have you any children? (BrE)

(2b) Do you have any children? (AmE)

(3a) Your daughter's name stands first in the list. (BrE)

(3b) Your daughter's name stands first on the list. (AmE)

(4a) Is Ann at home? (BrE)

(4b) Is Ann $\underline{\varnothing}$ home? (AmE)

(5a) I'll see you on Monday. (BrE)

(5b) I'll see you $\underline{\varnothing}$ Monday. (AmE)

Regarding the vocabulary, different dialects may apply different vocabulary to refer to the same meaning. For instance, the British English speakers express 'biscuits' and 'dustbin', instead of 'cookies' and 'trash can' spoken in the U.S to refer respectively to 'a small flat dry cake for one person, usually sweet, and baked until hard' and 'a container that holds materials that have been thrown away'.

(6a) We were offered a cup of tea and some biscuits. (BrE)

(6b) She put a batch of cookies into the oven. (AmE)

(7a) We put out the dustbins on a Wednesday morning before the van comes. (BrE)

(7b) She inspected a tee shirt of mine, sniffed it with disgust, and tossed it into a trash can across the room. (AmE)

Concerning the word spelling, the British and American English varieties differ in some aspects. For instance, the British English words 'metre' and 'colour' are spelt out 'meter' and 'color' respectively in American English as underlined in the following sentences.

(8a) Every few metres the cat stopped and turned to look at me. (BrE)

(8b) Meter is a metric measurement slightly longer than a yard. (AmE)

(9a) I'd like to paint this room in a lighter colour. (BrE)

(9b) The play had a good deal of color to it. (AmE)

The present research was designed to answer the question of whether or not the English covered in the English coursebook applied at school was a single dialect in term of grammar, vocabulary, and spelling. The findings were used to give input to the English coursebook writers to deliver English of a single variety consistently. It was also to identify whether the coursebooks delivered a single

Journal of English Language Teaching Innovations and Materials (Jeltim), 3(1), 39-47

Copyright ( 2021 by Jeltim, e-ISSN 2657-1617 
variety or more than one variety of English. The varieties were marked with vocabulary, grammar, and spelling.

\section{METHODOLOGY}

This research focused on investigating the English varieties delivered through the English coursebooks applied in Indonesia. They concerned the English varieties that were taught in Indonesia and the frequency of each English varieties. This research focused on the text of the English coursebook.

\section{Corpus}

The source of the research data was corpus. It typically refers to a collection of spoken or written texts mostly the whole works of a particular writer that writes a particular subject. It is mostly stored in "an electronic, machine-readable format" (Lange \& Leuckert, 2020) from which a researcher can reach 'all sorts of linguistic description and analysis" (Al-Gamal \& Ali, 2019) to study linguistic structures, frequencies, and so forth. The corpus may contain language variations, that is, 'different ways of saying the same thing' (Lange \& Leuckert, 2020).

In this research, the corpus was the English coursebook applied throughout Indonesia and published officially by the Ministry of Education and Culture. Besides, this book was registered in the International Standard Book Number (ISBN). This coursebook was entitled 'When English Rings a Bell'. This book was the main official resource for the teachers to deliver English to their students at school, and both the teachers and the students could have it in a hard-copy or download the soft-copy version.

This coursebook was written for the students attending Year 7 (Semester 1 and Semester 2 of Junior High School). It was completed with the teacher's book, too. It was firstly published in 2013 and its copyright belonged to the Ministry of Education and Culture. There were 3 contributors consisting of English teaching practitioners at the junior high schools; it was reviewed by 3 reviewers. This coursebook was completed with the forewords from the Minister of Education and Culture, the Republic of Indonesia.

\section{Procedure of Data Collecting}

The data were collected through the following procedure:

a. Identifying the data available in the corpus,

b. Sorting out the data from the corpus,

c. Classifying the data,

d. Counting the frequency of the data, and

e. Drawing the conclusion.

Journal of English Language Teaching Innovations and Materials (Jeltim), 3(1), 39-47

Copyright ( 2021 by Jeltim, e-ISSN 2657-1617 


\section{FINDING AND DISCUSSION}

\section{Findings}

The present research found out that the English forms delivered in the coursebook entitled 'When English Rings a Bell' were shared by both varieties, that is, the British English and the American English. There were English forms that were not shared between both varieties, which were classified as 'unique' forms in the present article. The number of the unique forms was very minor as can be seen in Graph 1. There was not any English form encountered in the coursebook from other English varieties, like Singaporean and Indian English.

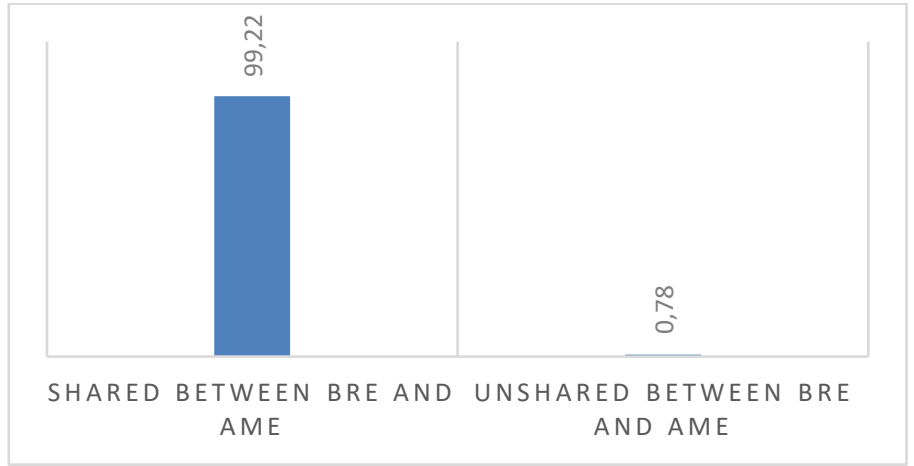

Graph 1. The shared and Unshared aspects between BrE and AmE in percentage

The language aspects that were only applicable to British English or American English covered vocabulary, spelling, and grammar. As can be seen in Graph 2, American English was delivered more frequently than British English in vocabulary and grammar, while British English was more frequently delivered than American English.

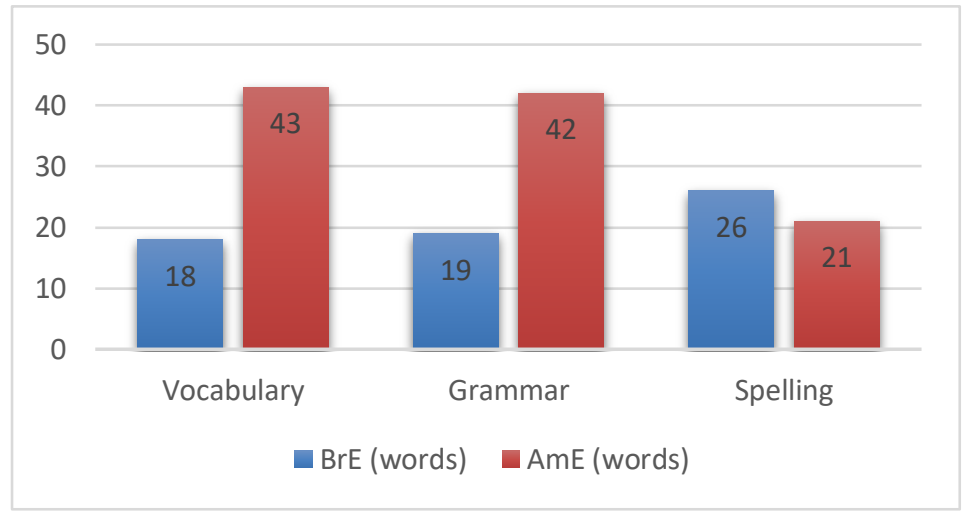

Graph 2. The unique forms applied only to BrE or to AmE 
The unique English varieties identified in the coursebook are illustrated in the following examples:

(10) Good night to you. (BrE spelling)

(11) Have you learned new words related to your daily life? (AmE spelling)

(12) On Mondays, I play football. (BrE Vocabulary)

(13) We must put the garbage in the garbage can. (AmE Vocabulary)

(14) I've got a flu. (BrE Grammar)

(15) How many brothers or sisters do you have? (AmE Grammar)

\section{Discussion}

The present research found out that there were two English varieties delivered in 'When English Rings a Bell'. They were British English and American English. Most of the language properties were shared by both varieties as illustrated in (16) and (17).

(16) Let me help you.

(17) I live in Biak, Papua.

The unique forms encountered in the coursebook 'When English Rings a Bell' were minor. They were applied inconsistently. The first inconsistency concerns vocabulary. For example, the word 'football' was written in the coursebook. It is spoken by British English speakers. The American English speakers use uniquely the word 'soccer', instead.

(18a) On Mondays, I play football. (BrE Vocab)

(18b) On Mondays, I play soccer. (AmE Vocab)

The second unique English properties encountered in 'When English Rings a Bell' dealt with grammar. This coursebook functioned 'do' as an auxiliary verb to construct an interrogative sentence or a negative sentence although the lexical verb was 'have'. This grammatical rule uniquely belongs to American English as shown in (19a). It is not applied in British English (Huddlestone, 1988). This latter variety permits the lexical verb 'have' meaning 'own, possess' to function as a lexical verb and an auxiliary verb in an interrogative or negative sentence. Thus, (19a) in American English is uniquely expressed (19b) in British English.

(19a) How many brothers or sisters do you have? (AmE Gram)

(19b) How many brothers or sisters have you? (BrE Gram)

On the other hand, the coursebook applied the past participle verb 'got' after the perfect auxiliary verb 'have' as illustrated in (20a). This grammatical rule is

Journal of English Language Teaching Innovations and Materials (Jeltim), 3(1), 39-47

Copyright ( 2021 by Jeltim, e-ISSN 2657-1617 
British English. American English applies 'gotten' after the auxiliary verb 'have' (Darragh, 2000) as seen in (20b).

(20a) I've got a flu. (BrE Grammar)

(20b) I've gotten a flu. (AmE Grammar)

The third finding concerns spelling. This coursebook spelt out the word 'night', not 'nite'. The former is British English and the latter American English. Inconsistently, this coursebook spelt out the word 'color' in c-o-l-o-r, American English, not c-o-l-o-u-r, British English (Darragh, 2000), as respectively shown below.

(21a) Good night to you. (BrE Spelling)

(21b) Good nite to you. (AmE Spelling)

(22a) My favorite color is green. (AmE Spelling)

(22b) My favorite colour is green. (BrE Spelling)

The inconsistency in the usage of the language forms as delivered in the coursebook may confuse the teachers and the students. They may not know what dialect the speakers speak. For example, in the context of American English, the forms 'take a bath' and 'take a rest' found out in the coursebook are expressed in 'have a bath' and 'have a rest' in British English. These forms refer to the same meaning respectively.

The choice of the language forms including vocabulary, grammar, and spelling as encountered in 'When English Rings a Bell' may show the association with the writers' social identity preference. Wardhaugh \& Fuller (2015) claims, "Orientation toward a particular language and, often, an associated national identity, is what makes speakers identify as speakers of language X or Y." Thus, the insertion of American English forms into the British English speech may offend the feelings of the British English interlocutors or vice versa.

Inserting the language forms of a particular dialect in a coursebook may also indicate the language forms that the writers master better. For example, the writers pick up the spelling 'r-e-a-l-i-s-e', instead of 'r-e-a-l-i-z-e'. The first spelling is British English; the second spelling is both British and American English (Darragh, 2000). The choice of the first spelling indicated that the writers preferred the British English variety to American English as their preference. If they did not emphasize this claim, the writers spelled out this word 'realize' to avoid the preference to one of them.

Journal of English Language Teaching Innovations and Materials (Jeltim), 3(1), 39-47 Copyright ( 2021 by Jeltim, e-ISSN 2657-1617 
There are factors that define students' language behaviour. Their language behaviour is determined effectively by the language exposed to the students (Sudarsono, Sutapa, \& Darsini, 2019). Thus, if the English coursebook exposes British English, for instance, the students will produce British English well. But, if they are exposed to mixed varieties like British English and American English, they will produce mixed varieties of British English and American English.

\section{CONCLUSION}

It is concluded that the coursebook entitled 'When English Rings a Bell' delivered and was written primarily in the forms shared by British and American English. However, the research found out that there were language forms that uniquely belonged to British English or American English. The unique forms here dealt with vocabulary, grammar, and spelling.

It will be wise if the writers deliver and write English coursebooks in a single English variety to avoid the potential offence to the feeling of a particular interlocutor. Besides, the students will produce their English behaviour as the varieties exposed by 'When English Rings a Bell'.

\section{REFERENCES}

Bauer, L. (2002). An Introduction to International Varieties of English. Edinburg: Edinburg University Press.

Darragh, G. (2000). A to ZED, A to ZEE: A guide to the differences between British and American English. Irun: Editorial Stanley.

Dash, N. (2005). Corpus Linguistics and Language Technology: With Reference to Indian Languages. New Delhi: Mittal Publications.

Huddlestone, R. (1988). English Grammar: an outline. Cambridge: Cambridge University Press.

Hutchinson, T., \& Torres, E. (1994). The textbook as agent of change. ELT Journal Volume 48/4, 315-328.

Sudarsono. (2018). Ungrammatical Construction: Study on texts written by test takers to postgraduate of English Language Education, Tanjungpura University. In R. A. Bakar, S. A. Rahim, \& F. N. Tazijan, Creativity in Teaching and Learning: A blueprint for success (pp. 29-34). Permatang Pauh: Universiti Teknologi MARA Cawangan Pulau Pinang.

Sudarsono, S., Sutapa, G., \& Darsini, F. (2019). Early Media Viewing Impacts. Borneo Akcaya, 73-83. 
Waltermann, E., \& Forel, C. (2015). Why and how to include textbook analysis in language teacher education programs. ELTED 18, 43-48.

Wardhaugh, R., \& Fuller, J. M. (2015). An Introduction to Sociolinguistics. 7th edition. Oxford: Wiley Blackwell.

Zacharias, N. T. (2003). A survey of tertiary teachers' beliefs about English Language Teaching in Indonesia with regard to the role of English as a global language. MA-ELT Thesis. Bangkok: Assumption University of Thailand.

\section{Authors' Brief CV}

Yuni Hardianti completed her Undergraduate in ELT at IKIP-PGRI Pontianak her master's degree in ELT at the Faculty of Teacher Training and Education of Universitas Tanjungpura, Pontianak - Indonesia. Currently she is a teacher of English and Math in Pontianak.

Sudarsono has been teaching at Tanjungpura University since 1987. He obtained his doctoral degree in Linguistics from La Trobe University, Australia. His main job is teaching linguistics-related subjects like grammar, second language acquisition, and bilingualism. He has done research on language analysis, sociolinguistics, and vernaculars. 